\title{
Collecting birds: the importance of moral debate
}

\author{
MARC BEKOFF and ANDRZEJ ELZANOWSKI
}

In a recent article in this journal, Remsen (1995) attacked moral (and other) objections to killing birds for museum collections, objections that are frequently raised by the general public and scientific community alike. The only grounds for moral objections against killing birds that Remsen considers and rejects are reverence for all life or personal (p. 157; all page references refer to Remsen 1995), that is sentimental (p. 165) reasons. What Remsen ignores is avian sentience and the moral imperative of respecting it.

Birds, like mammals, are highly sentient beings (Skutch 1996) who can experience great amounts of distress and pain (Elzanowski 1991, Gentle 1991; 1992, Mench 1991). Sentience provides a generally recognized and scientifically grounded rationale for legitimate moral concerns about individuals (Dawkins 1980, 1990, Bekoff and Jamieson 1991, Elzanowski 1993, Broom and Johnson 1993, Bekoff 1994, 1995a, Webster 1994, DeGrazia 1996, Putnam 1996). Among other things, being sentient means having individual interests, and the respect for individual interests lies at the very basis of any rational ethics. Highly debatable, of course, is how conflicts of interests are to be resolved. For example, Loftin (1992) offers a set of eight criteria that he believes need to be considered for justifiably collecting animals, and while we do not necessarily agree with his views, at least he has attempted to argue for an ethical position (see also Putnam 1996). This is something that Remsen has not done. What compromises Remsen's advocacy is the manner in which he dismisses legitimate concerns about individual birds.

Although some collectors try to be humane, no humane standards are institutionally enforced for collecting (as opposed to other types of research involving wild animals) in the U.S.A. and most other countries. In the U.S.A., the only written standards are two paragraphs of the "Guidelines for use of wild birds in research" (Oring et al. 1988), which require that killing be instantaneous, either by shooting or by squeezing (or pithing) small birds and cervical dislocation for large birds, and provide some humane recommendations for mist-netting. However insufficient, there is no requirement that these rules be known, let alone enforced, by collectors. Neither humane education nor training in handling and killing birds is required for obtaining collecting permits.

Some current collecting practices are clearly inhumane. While squeezing small sparrow-sized birds seems to cause an instantaneous death (although some taxonomic differences have been noted by experienced collectors) it may take several minutes to squeeze to death medium-size birds, such as nightjars. Some collectors keep live (and half-suffocated) birds in collecting bags (or pockets) for 
hours before killing and preserving them (especially to prevent the early onset of decay in the tropics). In addition, birds are commonly collected during the breeding season, which causes starvation and death to individuals who depend on the collected individuals (this issue, known under the euphemism "collateral damage", is not addressed in the Guidelines). Remsen's statement that birds are collected "usually in the most humane way possible" (p. 157) remains an unsubstantiated claim.

In Remsen's view, any consideration of animal welfare is "counterproductive" in the context of research and conservation, although this is not a consensus view even among conservationists (see various chapters in Cooper and Carling 1996). While we recognize the importance of museum collections for research and conservation, we oppose Remsen's hierarchy of values, with science and conservation placed so far above morality (and law) that any moral (and legal) objections that may interfere with the pursuit of these supreme goals should be discarded (p. 145). The elevation of supraindividual goals and entities (such as populations, species, gender, races, ecosystems, economies) above morality simply promotes another morality that is based on supraindividual values. The suppression of individual interests in the name of supraindividual values is as old as human civilization and has culminated in many devastating outbreaks of oppression and aggression.

Remsen believes that "morality is not a proper subject for scientific debate" (p. 157) but widely uses scientific facts to support his hierarchy of values, and engages in the sort of debate in which he claims he and other scientists should not be involved. Remsen's main claim for the moral irrelevance of killing birds is their high mortality "from natural but painful causes", whereas scientists "sacrifice" only a few individuals (p. 157). In fact, the quality and quantity of deaths due to natural causes is irrelevant in attempts to justify the pain and suffering inflicted by collecting practices. Remsen's attempts to derive a moral judgement from nature is a well-known fallacy. Nature is amoral and non-human animals (perhaps with the partial exception of some non-human primates) are not morally responsible for their actions. However, scientists are morally responsible for their actions and appeals to nature's brutality will not relieve them of this responsibility (Bekoff and Hettinger 1994).

It is true that all the suffering inflicted by scientists seems to be small when compared with that resulting from other human activities. But this is a reason for more rather than less concern about individual birds on the part of ornithologists, who are not merely one of the many interest groups that depend on using birds. Ornithologists bear more responsibility because they are supposed to know more about birds than others who use these vertebrates. The way ornithologists treat birds sets an example for everybody else and frequently translates into laws via testimonies to legislative bodies. The way ornithologists treat "their" birds affects the way birds are treated by other humans.

Another scientific reason why, in Remsen's view, individual bird lives are of little if any importance is that "most individual birds live only a few years" (p. 157), which amounts to using average life expectancy as an objective, scientific measure of value of life. This is a rather curious bioethical proposal that Remsen himself does not seem to take seriously, as he does not make special provisions 
for killing such long-lived birds as albatrosses and parrots (the latter with cognitive skills comparable to that of many non-human primates). Instead, he attempts to ridicule concerns about individual birds: "I wonder whether those who oppose scientific collecting of birds also refrain from consuming tuna, swordfish, octopus, lobster, large crabs, abalone, and other large, long-lived wild animals" (p. 158). Many people who share our concerns indeed refrain from eating all or at least some of these animals because of concerns for individual animals and the environment.

According to Remsen, "the goal of scientists, conservation agencies, and governments is protection of populations, not individual birds" (p. 145). With respect to conservation agencies this claim is a platitude. Governments are supposed to implement policies that reflect public concerns, and public concerns about animal welfare are at least comparable to those about conservation (Kellert 1996). The public is becoming less tolerant of the use of animals in research (Rowan 1995) and the lack of sensitivity to legitimate public concerns on the part of museum scientists is likely to decrease public support for museum and other types of research. As far as life scientists are concerned, some work to improve conservation while others work to improve animal welfare (many chairs of animal welfare have been established recently in Europe and North America). However, a primary goal of science is to provide society with a realistic picture of nature. Because too many ornithologists ignore avian sentience and its implications, today's ornithology conveys a distorted, impoverished picture of birds and deprives the public from the benefits of informed interactions with fellow sentient beings, benefits that some ornithologists come to appreciate (Skutch 1996).

Remsen also believes that most museum scientists "find the killing of birds necessary but distasteful" (p. 165), and some museum scientists realize that their distaste reflects a serious moral problem. We urge these individuals to cooperate in developing new, more humane approaches to collecting. New humane principles and techniques can be tested and implemented only by the practitioners in a field, which is why the possibility of humane refinements and alternatives cannot be realistically assessed as long as collecting continues to be done with a disregard for the interests of individual birds that characterizes Remsen's advocacy.

Our general conclusions concur with those reached by Cuthill (1991) that "just as we should be prepared to inform the public of the scientific value of our research, we should also be prepared to discuss any ethical costs it entails". Open-minded scepticism about the goals and practice of science is healthy and will make for better and more responsible science (Bekoff 1995b, Bekoff and Jamieson 1996). In particular, we conclude that killing birds for collections requires as serious education, practical training, and oversight of their use in research; that moral objections to current collecting practices are well justified; and that a new, more responsible ethic and practice of collecting sentient animals needs to be developed and implemented. Museum research and conservation should respect individual interests of sentient animals, whatever the conservation status of a species. Those who harm sentient beings must be held accountable for and justify their behavior in ethical, not in technical (scientific) terms. 


\section{Acknowledgements}

M. B. thanks Ned Hettinger, Dale Jamieson, Lori Gruen, Carron A. Meaney, and Susan E. Townsend for discussion. A. E. thanks Gary Graves and Richard Zusi for their criticism of an earlier version.

\section{References}

Bekoff, M. (1994) Cognitive ethology and the treatment of non-human animals: how matters of mind inform matters of welfare. Anim. Welfare 3: 75-96.

Bekoff, M. (1995a) Marking, trapping, and manipulating animals: some methodological and ethical considerations. Pp. 31-47 in K. A. L. Bayne and M. D. Kreger, eds., Wildlife mammals as research models: in the laboratory and field. Greenbelt, Maryland: Scientists Center for Animal Welfare.

Bekoff, M. (1995b). Naturalizing and individualizing animal well-being and animal minds: an ethologist's naiveté exposed? Pp. 63-129 in A. Rowan, ed., Wildlife conservation, zoos, and animal protection: a strategic analysis. Grafton, Mass.: Tufts Center for Animals and Public Policy.

Bekoff, M. and Hettinger, N. (1994) Animals, nature, and ethics. J. of Mammalogy 75: 219223.

Bekoff, M. and Jamieson, D. (1991) Reflective ethology, applied philosophy, and the moral status of animals. Perspect. Ethol. 9: 1-47.

Bekoff, M. and Jamieson, D. (1996) Ethics and the study of carnivores: doing science while respecting animals. P. $15-45$ in J. L. Gittleman, ed., Carnivore behavior, ecology, and evolution: 2. Ithaca, N.Y.: Cornell University Press.

Broom, D. M. and K. G. Johnson. (1993) Stress and animal welfare. London: Chapman and Hall.

Cooper, N. S. and R. C. J. Carling, eds. (1996) Ecologists and ethical judgements. London: Chapman and Hall.

Cuthill, I. (1991) Field experiments in animal behaviour: methods and ethics. Anim. Behav. 42: 1007-1014.

Dawkins, M. S. (1980) Animal suffering: the science of animal welfare. London: Chapman and Hall.

Dawkins, M. S. (1990) From an animal's point of view: motivation, fitness, and animal welfare. Behav. Sci. 13: 1-61.

DeGrazia, D. (1996) Taking animals seriously: Mental life and moral status. Cambridge University Press.

Elzanowski, A. (1991) Motivation and subjective experience in birds. 2oth International Ornithological Congress, Acta: 1921-1929.

Elzanowski, A. (1993) The moral career of vertebrate values. Pp. 259-276 in M. H. Nitecki and D. V. Nitecki, eds., Evolutionary ethics, Albany, N.Y.: State University of New York Press.

Gentle, M. J. (1991) Behavioural and physiological responses to pain in the chicken. 2oth International Ornithological Congress, Acta: 1915-1920.

Gentle, M. J. (1992) Pain in birds. Anim. Welfare 1: 237-247.

Kellert, S. (1996) The value of life: Biological diversity and human society. Washington, D. C.: Island Press.

Loftin, R. W. (1992) Scientific collecting. Environ. Ethics 14: 253-264.

Mench, J. A. (1991) Stress in birds. 2oth International Ornithological Congress, Acta: 19051914.

Oring, L. W., Able, K. P., Anderson, D.W., Baptista, L. F., Barlow, J. C., Gaunt, A. S. Gill, F. B. and Wingfield, J.C. (1988) Guidelines for Use of Wild Birds in Research. Auk 105 (Suppl.): 1a-41a. 
Putnam, R. J. (1996) Ethical considerations and animal welfare in ecological field studies. Pp. 123-135 in Cooper, N. S. and Carling, R. C. J. eds. Ecologists and ethical judgements. London: Chapman and Hall.

Remsen, J. V. (1995) The importance of continued collecting of bird specimens to ornithology and bird conservation. Bird Conserv. Int. 5: 145-180.

Rowan, A. (1995) Scientists and animal research. Dr Jekyll or Mr Hyde. Soc. Res. 62: 787800.

Skutch, A. F. (1996) The minds of birds. College Station: Texas A \& M University Press.

Webster, J. (1994) Animal welfare. A cool eye towards Eden. Oxford: Blackwell.

\section{MARC BEKOFF}

Environmental, Population, and Organismic Biology, University of Colorado, Boulder, Colorado 80309-0334, U.S.A.

\section{ANDRZEJ ELZANOWSKI}

Scientific Advisory Council to The Humane Society of the United States, 7oo Professional Drive, Gaithersburg, Maryland 20879, U.S.A. 